\title{
ANALÝZA KONKURENCIE V ODVETVÍ POŠTOVÝCH SLUŽIEB
}

\author{
Iveta Kremeňová $^{1}$ Jana Palková$^{2}$
}

Ak hovoríme o liberalizácii poštových služieb, ide o proces odstraňovania prekážok slobodného podnikania na poštovom trhu. Poštový trh sa pomaly otvára konkurencii a postavenie poskytovatel'ov univerzálnej služby je stále viac ohrozené. Nielenže prichádzajú noví poskytovatelia poštových služieb, ale aj poštová výhrada, ktorá predstavuje určitú formu kompenzácie za povinnost' poskytovat' univerzálnu službu, a ktorá ho oprávňuje poskytovat' určité služby do stanovených cenových a hmotnostných limitov, sa postupne znižuje.

\section{Porterov model konkurenčných síl}

V tomto článku sa preto zameriavame na analýzu rozvoja konkurencie v odvetví poštových služieb. Odvetvie pozostáva zo skupiny podnikov, ktoré vyrábajú produkty alebo služby, ktoré uspokojujú tú istú potrebu spotrebitel'ov, a ktoré sa môžu vzájomne nahradit'. Rozhodujúcim pre tvorbu stratégie každého podniku je odpovedanie si na otázky: „Aké sily pôsobia na vývoj konkurencie v danom odvetví? Aká je konkurencia v danom odvetví? Čo pripravujú konkurenti a čo môžeme od nich očakávat' (v ktorých trhových segmentoch možno očakávat' vstup nových poskytovatel'ov poštových služieb a v ktorých je vstup nepravdepodobný)? Najrozšírenejšou technikou konkurenčnej analýzy je Porterov model piatich konkurenčných síl. Hovorí o piatich základných silách, ktoré pôsobia na každé odvetvie a určujú rozsah sút’aživosti v ňom, sú to:

1. Rivalita medzi existujúcou konkurenciou (konkurencia medzi existujúcimi konkurentmi).

2. Riziko vstupu nových konkurentov do odvetvia (konkurencia zo strany nových konkurentov).

3. Obchodná sila kupujúcich (konkurencia zo strany zákazníkov).

4. Obchodná sila dodávatel'ov (konkurencia zo strany dodávatel'ov).

5. Hrozba potenciálnych vstupov (konkurencia zapríčinená pôsobením substitútov). Popri týchto piatich silách poukázal Porter na dve dodatočné sily:

1. Sila zamestnancov - správanie robotníkov a odborov môže podstatne znížit' zisk podniku.

2. Š́tátne opatrenia [2].

Pomocou štátnych opatrení (právne predpisy, subvencie, podpora náhradných produktov, daňové povzbudenie, atd'.) môže štát vývoj v odvetví rozhodujúco ovplyvnit'.

\footnotetext{
${ }^{1}$ Doc. Ing. Iveta Kremeňová, Katedra spojov, Fakulta prevádzky a ekonomiky dopravy a spojov, Žilinská univerzita v Žiline, Univerzitná 1, 01026 Žilina, Slovenská republika, tel.: +421415133108 , fax:+421415655615 e-mail: Iveta.Kremenova@fpedas.utc.sk

${ }^{2}$ Ing. Jana Palková, Katedra spojov, Fakulta prevádzky a ekonomiky dopravy a spojov, Žilinská univerzita v Žiline, Univerzitná 1, 01026 Žilina, Slovenská republika, tel.: +421415132025 , fax: +421415655615 e-mail: Jana.Palkova@fpedas.utc.sk
} 
Vládna politika ovplyvňuje vstup do odvetvia poštových služieb, ceny služieb a strategické správanie spoločností.

Vzt’ah medzi týmito silami v poštovom odvetví znázorňuje obrázok 1.

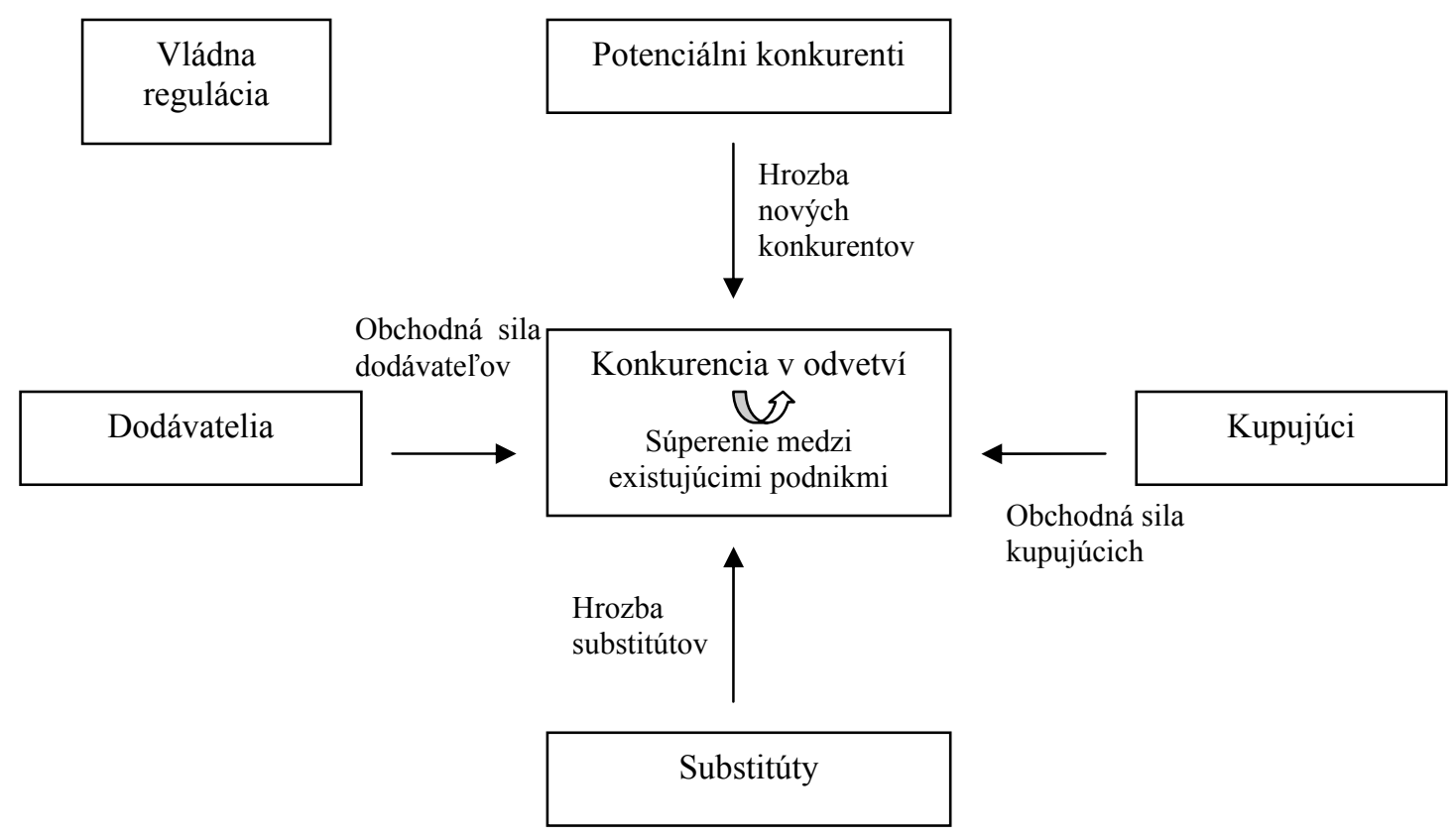

Obrázok 1 Porterov model piatich síl [1]

\section{Hrozba vstupu nových konkurentov do odvetvia}

Potenciálnych konkurentov predstavujú podniky, ktoré ešte v súčasnosti nepôsobia v danom odvetví, ale majú schopnost' do neho vstúpit'. Sú to spravidla podniky z príbuzných odvetví, ktoré využívajú podobnú technológiu, majú skúsenosti s daným trhom, alebo majú dostatok kapitálu pre vstup do daného odvetvia. Vstup nových konkurentov do odvetvia znamená pre etablované podniky, že budú t’ažšie udržiavat' svoj podiel na trhu, priaznivú výšku cien a úroveň dosahovaných ziskov. Tlak potenciálnych konkurentov a ich snaha vstupovat' do odvetvia nezávisí iba od ich schopností, ale aj od vonkajších podmienok odvetvia. Č́m vyššie sú bariéry vstupu do odvetvia, tým sú vyššou prekážkou pre vstup nových konkurentov.

Pre služby vo vyhradenej oblasti nie je žiadna hrozba vstupu nových konkurentov. V súvislosti s liberalizáciou poštového trhu sa plánuje táto oblast' úplne zrušit'. Očakáva sa, že poskytovat' univerzálnu službu budú aj po úplnej liberalizácie jej súčasní poskytovatelia, národní poštoví operátori. Vstup nového konkurenta sa očakáva do segmentu adresných poštových zásielok od spoločností, ktoré sú už aktívne v určitom (liberalizovanom) segmente poštových zásielok alebo sú zapojené do určitého stupňa hodnotového ret'azca. Môžu to byt' napríklad spoločnosti, ktoré sa zaoberajú doručovaním neadresných zásielok, vel'kí odosielatelia, zásielkové domy, vydavatel'stvá a poskytovatelia databáz adries. Je tu možný tiež vstup poštových operátorov z iných krajín, ktorí chcú rozširovat' svoju pôsobnost' aj na zahraničných trhoch.

\section{Hrozba možných substitútov}

Okrem podnikov etablovaných v odvetví môžu byt' konkurentmi aj podniky z iných odvetví, ktoré uspokojujú podobné potreby zákazníka ako podniky z daného odvetvia. 
Substitúty sú nebezpečné, ak sa stávajú prít’ažlivejšími pre zákazníkov, pokial' ide o cenu a kvalitu.

Pre trh poštových služieb predstavuje túto hrozbu komunikačný trh, trh reklamy a dopravný/logistický trh. Vo viacerých trhových segmentoch nastáva nárast využívania substitútov, napr. v medzil'udskej komunikácii sa čím d’alej častejšie, namiesto listových zásielok, využívajú alternatívne spôsoby komunikácie, a to telefón, SMS a e-mail.

V komunikácii firiem so svojimi zákazníkmi sa využíva internet (elektronické zúčtovanie, elektronické bankovníctvo). Rovnako trh reklamy ponúka dôležité substitučné produkty pre reklamné zásielky, a to reklama $\mathrm{v}$ televízii, $\mathrm{v}$ rádiu alebo $\mathrm{v}$ novinách a časopisoch a tiež na internete. Súčasne sa tu ukazuje príležitost' a to v prípade marketingovej kampane, ktorá je zameraná na priblíženie daného podniku zákazníkom, a ktorá je realizovaná kombináciou reklamy na internete, reklamnými zásielkami a call centrami. Obrázok 2 ukazuje poštový trh vo vzt'ahu s komunikačným, reklamným a dopravným/logistickým trhom.

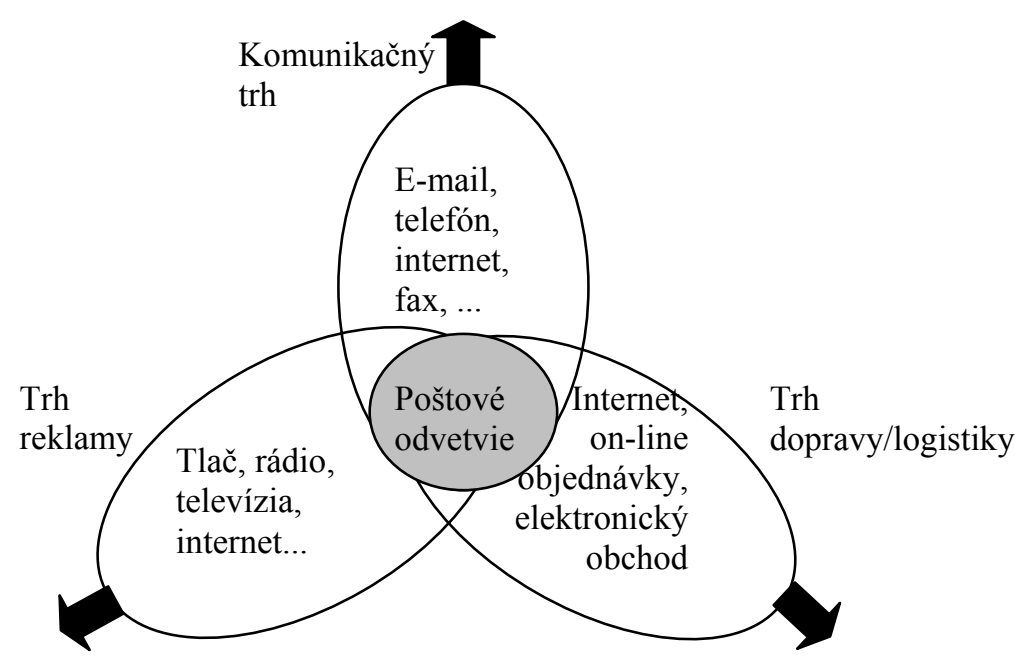

Obrázok 2 Strategické umiestnenie trhu poštových služieb [1]

\section{Obchodná sila kupujúcich}

Kupujúci, ktorí podnikajú v iných nadväzujúcich odvetviach, môžu mat' rôznu silu, schopnost' presadzovat' svoje záujmy u podnikov v danom odvetví. Obvykle sa to týka požiadaviek na kvalitu, ceny, rozsahu služieb, termínov dodávok a pod. Môžu vyvíjat' tlak na podniky, aby neustále zvyšovali kvalitu produkcie alebo znižovali cenu. Tiež môžu od nich požadovat' rad výhod ako obchodné úvery, špeciálne platobné podmienky, doplnkový servis a pod.

Konkurenčná sila kupujúcich poštových služieb je obzvlášt’ vel'ká v oblasti komunikácie firiem so svojimi zákazníkmi a tiež v oblasti komunikácie medzi podnikmi. Vel'kí zákazníci, ako banky, poist'ovne a vydavatel'stvá disponujú najväčšou kúpnou silou, a z toho dôvodu môžu vyvíjat' nátlak na poštových operátorov. Môžu znižovat' frekvenciu doručovania (napr. bankové výpisy), môžu sa zaujímat' o doručenie svojich poštových zásielok alebo tak, že hl'adajú doplnkové spôsoby komunikácie so svojimi klientmi. Jedným zo spôsobov je zasielanie korešpondencie s vyššou hmotnost'ou, ako je hmotnostný limit pre vyhradenú oblast'. Po liberalizácii adresných poštových zásielok nad $50 \mathrm{~g}$ sa táto hrozba stáva skutočnost'ou. 
V oblasti komunikácie medzi osobami je vel'mi malá sila kupujúcich. V oblasti komunikácie zákazníkov s podnikmi môže byt' tiež vyvíjaný nátlak na poštových operátorov, a to napr. prostredníctvom odpovedných zásielok. Konkurenčná sila vel'kých zákazníkov sa zvýši po úplnej liberalizácii poštového odvetia, z dôvodu existencie viacerých poštových operátorov.

\section{Obchodná sila dodávatel'ov}

Dodávatelia zdrojov môžu vytvárat' tlak na dané odvetvie a môžu spôsobit' zvýšenie cien výstupov alebo zníženie kvality.

Dodávatelia vstupov poštovým operátorom (napr. výrobcovia triediaceho zariadenia alebo dopravca) nemajú zvláštne postavenie, pokial ide o stanovenie ceny služieb, frekvenciu doručovania alebo o pokrytie doručovacou siet'ou. Ale ovplyvňujú obchodný model poštových operátorov prostredníctvom rozvoja technológií pre poštový sektor.

\section{Rivalita medzi existujúcimi podnikmi}

Súperenie medzi podnikmi pôsobiacimi v tom istom odvetví môže nadobúdat' rôznu formu - od tvrdého zápasu o získanie postavenia na trhu až po vzájomné dohody v snahe vyhnút' sa zbytočným nákladom a stratám na zisku. Konkurenčné pôsobenie môže byt' obmedzené na jednu dimenziu (napr. cena) alebo na viac dimenzií (kvalita výrobkov, reklama, inovácie výrobkov, obchodné úvery a pod.).

Konkurencia medzi poštovými operátormi v oblasti adresných zásielok je ešte vel'mi ohraničená a všetci národní poštoví operátori (v rámci EÚ) si udržujú trhový podiel nad 90 \% v oblasti doručovania adresných zásielok. Možno však tiež vidiet', že niektorí národní poštoví operátori stratili značný trhový podiel v doručovaní neadresných zásielok, tiež v doručovaní balíkov a rovnako to platí aj pre expresné služby. Krajiny, ktoré majú liberalizovanú pomerne vel'kú čast' adresných zásielok, vykazujú najvyšší trhový podiel konkurenčných poštových operátorov takto: 7-11 \% v Španielsku, 5-7 \% v Českej republike, Estónsku, Holandsku a Švédsku a 3-5 \% v Dánsku a Nemecku.

\section{Pravdepodobnost' vstupu nových konkurentov}

V úplne liberalizovanom trhu úroveň skutočnej konkurencie na trhu pozitívne ovplyvňuje najmä kombinácia obchodnej sily vel'kých zákazníkov a potenciálni a existujúci konkurenti na trhu.

Vstup je najviac pravdepodobný do oblastí, ktoré nevyžadujú vel'kú fixnú siet'. Požiadavky na siet' sú menšie, ked' sa vstup uskutoční iba do určitej časti zásobovacieho ret’azca. Pre vstupujúcich:

- sú atraktívnejšie vel'ké zásielky ako individuálne zásielky,

- homogénne štandardizované zásielky sú atraktívnejšie ako heterogénne zásielky,

- služby s pridanou hodnotou sú atraktívnejšie ako služby, ktoré sú štandardne ponúkané,

- zásielky od firiem sú atraktívnejšie ako zásielky od obyvatel'stva,

- zásielky, ktoré nie sú citlivé na čas, sú atraktívnejšie, ako zásielky vyžadujúce doručenie nasledujúci deň,

- doručovanie do P.O.Boxov a doručovanie do zal'udnených oblastí je atraktívnejšie ako doručovanie po celom území,

- doručovanie niekol'kokrát za týždeň je atraktívnejšie ako doručovanie pät'- alebo šest'krát za týždeň.

Príčiny, prečo sa konkurencia nemôže vyvíjat', sú spojené s l'ubovol'nými charakteristikami prirodzeného monopolu (časti) poštového trhu, existencie silnej výhody prvého účastníka alebo iné bariéry vývoja konkurencie. 


\section{Vplyvy konkurencie na trhu}

Existencia konkurencie môže byt' pozorovaná na správaní niektorých národných poštových operátorov $\mathrm{v}$ rámci EÚ a na ich trhovom výkone:

- liberalizácia vo Švédsku viedla Švédsku poštu k lepším výkonom vo vzt’ahu k zákazníkom a efektívnosti nákladov, v Holandsku a Španielsku liberalizácia prispela k zvýšeniu výkonov TNT a Coreios,

- ceny za nočné doručovanie individuálnych zásielok vo Švédsku vzrastajú, ceny iných produktov sú rovnaké alebo klesajú,

- pozícia vel'kých zákazníkov voči národným poštovým operátorom zosilnila pre poštové produkty v liberalizovanej oblasti,

- pomer cena/kvalita reklamných (adresných) zásielok sa zlepšil ako výsledok vývoja nových produktov a obchodných modelov, všeobecne sa tento pomer zvyšuje.

\section{Očakávaný vývoj na trhu}

Očakáva sa, že vel'kost' trhu poštových zásielok (celkový objem) v tomto roku mierne poklesne alebo zostane nezmenený. Všade v EÚ sa očakáva pokles objemu obchodných zásielok $\mathrm{v}$ dôsledku existencie elektronických substitútov (napr. odhady poklesu bankových výpisov sa pohybujú v rozmedzí $1-25 \%$, platieb vel'kým podnikom $1-20 \%$, individuálnych zásielok $0-15 \%$ ). Predpokladá sa, že objem časopisov a katalógov zostane nezmenený a objem podaných reklamných zásielok má zostat' tiež nezmenený, prípadne by mal mierne narást' [1].

\section{Záver}

Stratégie národných poštových operátorov sú ovplyvnené vývojom na trhu. Tradičná príjmová základňa sa zmenšuje. Pôsobením konkurentov na trhu sa zmenšuje objem zásielok spracovávaný národným poštovým operátorom. Reklamný a komunikačný trh vyvíja nové produkty.

V dôsledku tohto vývoja je potrebné zlepšit' efektívnost' poskytovania poštových služieb a rozšírit' príjmovú základňu bud' na domácom trhu (služby s pridanou hodnotou, expresné, logistické a/alebo finančné služby) alebo na medzinárodnom trhu (hlavne expresný, logistický trh, trh so zahraničnými listovými zásielkami a balíkovými zásielkami) alebo na obidvoch trhoch. Často $\mathrm{k}$ dosiahnutiu tohto sú potrebné značné investície, ktoré môžu byt' financované aj zahraničným kapitálom.

\section{Literatúra}

[1] Studie über die Entwicklung des Wettbewerbs im Europäischen Postsektor (Ecorys - Juli 2005) [online]. [Cit. 2006-03-03]. Dostupné na: $<$ http://europa.eu.int/comm/internal_market/post/doc/studies/2005-ecorys-final_en.pdf $>$

[2] Roman Lombriser/Peter A. Abplanalp: Strategisches Management Visionen entwickeln, Strategien umsetzen, Erfolgspotenziale aufbauen, Versus Verlag AG, Zürich 2005, ISBN: 3039090496

[3] Skúmanie externého prostredia podniku. [skriptá]. [online]. [Cit. 2006-03-03]. Dostupné na: $<$ http://www.econ.umb.sk/upload/predmety/218/2005\%20PPS\%20skripta\%20kap3.pdf> 